\title{
Article \\ Cashew Gum (Anacardium occidentale) as a Potential Source for the Production of Tocopherol-Loaded Nanoparticles: Formulation, Release Profile and Cytotoxicity
}

\author{
Kahynna C. Loureiro ${ }^{1,2}$, Alessandro Jäger ${ }^{2}$, Ewa Pavlova ${ }^{3}$, Isabel B. Lima-Verde ${ }^{4}$, Petr Štěpánek ${ }^{2}$, \\ Leandro S. Sangenito ${ }^{5}$, André L. S. Santos ${ }^{5} \mathbb{D}^{\circ}$, Marco V. Chaud ${ }^{6}{ }^{\mathbb{D}}$, Hernane S. Barud ${ }^{7}$, Mônica F. La R. Soares ${ }^{8} \mathbb{D}^{\mathbb{D}}$, \\ Ricardo L. C. de Albuquerque-Júnior ${ }^{1}$, Juliana C. Cardoso ${ }^{1} \mathbb{D}$, Eliana B. Souto ${ }^{9,10, *}$, Marcelo da Costa Mendonça ${ }^{1}$ \\ and Patrícia Severino $1, *$ (D)
}

Citation: Loureiro, K.C.; Jäger, A.; Pavlova, E.; Lima-Verde, I.B.; Štěpánek, P.; Sangenito, L.S.; Santos, A.L.S.; Chaud, M.V.; Barud, H.S.; Soares, M.F.L.R.; et al. Cashew Gum (Anacardium occidentale) as a Potential Source for the Production of Tocopherol-Loaded Nanoparticles: Formulation, Release Profile and Cytotoxicity. Appl. Sci. 2021, 11, 8467. https://doi.org/10.3390/app11188467

Academic Editor: Gang Ma

Received: 14 July 2021

Accepted: 9 September 2021

Published: 12 September 2021

Publisher's Note: MDPI stays neutral with regard to jurisdictional claims in published maps and institutional affiliations.

Copyright: (c) 2021 by the authors. Licensee MDPI, Basel, Switzerland. This article is an open access article distributed under the terms and conditions of the Creative Commons Attribution (CC BY) license (https:/ / creativecommons.org/licenses/by/ $4.0 /)$.
1 Institute of Technology and Research (ITP), Tiradentes University, Av. Murilo Dantas 300 , Aracaju 49010-390, SE, Brazil; kahynna@live.com (K.C.L.); ricardo_albuquerque@unit.br (R.L.C.d.A.-J.); juliana_cordeiro@itp.org.br (J.C.C.); marcelo_costa@unit.br (M.d.C.M.)

2 Department of Supramolecular Polymer Systems, Institute of Macromolecular Chemistry, Heyrovského Námestí 2, 16206 Prague 6, Czech Republic; alejager@gmail.com (A.J.); stepanek@imc.cas.cz (P.Š.)

3 Department of Morphology of Polymer Materials, Institute of Macromolecular Chemistry, Heyrovského Námestí 2, 16206 Prague 6, Czech Republic; pavlova@imc.cas.cz

4 Department of Clinical Sciences, Swedish University of Agricultural Sciences, 7054, 75007 Uppsala, Sweden; isabel_limaverde@yahoo.com.br

5 Laboratório de Estudos Avançados de Microrganismos Emergentes e Resistentes, Departamento de Microbiologia Paulo de Góes, Universidade Federal do Rio de Janeiro, Rio de Janeiro 21941-902, Brazil; ibastefano@hotmail.com (L.S.S.); andre@micro.ufrj.br (A.L.S.S.)

6 Department of Technological and Environmental Processes, Universidade de Sorocaba (UNISO), Rod. Raposo Tavares, Km 92.5, Sorocaba 18023-000, SP, Brazil; marco.chaud@prof.uniso.br

7 Laboratório de Biopolímeros e Biomateriais (BioPolMat), Universidade de Araraquara-Uniara, Araraquara 14801-320, SP, Brazil; hernane.barud@gmail.com

8 Quality Control Core of Medicines and Correlates (NCQMC), Department of Pharmaceutical Sciences, Federal University of Pernambuco, Recife 50740-520, PE, Brazil; monica.soares@ufpe.br

9 CEB - Centre of Biological Engineering, University of Minho, Campus de Gualtar, 4710-057 Braga, Portugal

10 Department of Pharmaceutical Technology, Faculty of Pharmacy, University of Coimbra, Pólo das Ciências da Saúde, Azinhaga de Santa Comba, 3000-548 Coimbra, Portugal

* Correspondence: eliana.souto@ceb.uminho.pt (E.B.S.); patricia_severino@itp.org.br (P.S.)

Abstract: Every year, more than thirty thousand tons of Cashew gum (Anacardium occidentale, family: Anacardiaceae) are produced in Brazil; however, only a small amount is used for different applications in foodstuff and in pharmaceutical industries. As a raw material for the production of drug delivery systems, cashew gum is still regarded as an innovative compound worth to be exploited. In this work, cashew gum was extracted from the crude exudate of cashew tree employing four methodologies resulting in a light brown powder in different yields $(40.61 \%$ to $58.40 \%)$. The total ashes $(0.34 \%$ to $1.05 \%$ ) and moisture $(12.90 \%$ to $14.81 \%)$ were also dependent on the purification approach. FTIR spectra showed the typical bands of purified cashew gum samples, confirming their suitability for the development of a pharmaceutical product. Cashew gum nanoparticles were produced by nanoprecipitation resulting in particles of low polydispersity $(<0.2)$ and an average size depending on the percentage of the oil. The zeta potential of nanoparticles was found to be below $20 \mathrm{mV}$, which promotes electrostatic stability. Encapsulation efficiencies were above $99.9 \%$, while loading capacity increased with the increase of the percentage of the oil content of particles. The release of the oil from the nanoparticles followed the Korsmeyer-Peppas kinetics model, while particles did not show any signs of toxicity when tested in three distinct cell lines (LLC-MK2, HepG2, and THP-1). Our study highlights the potential added value of using a protein-, lignans-, and nucleic acids-enriched resin obtained from crude extract as a new raw material for the production of drug delivery systems.

Keywords: cashew gum; nanoparticles; tocopherol; resin; drug delivery; nanoprecipitation 


\section{Introduction}

Cashew gum (CG) is a complex heteropolysaccharide widely produced in the north and northeast of Brazil from the Anacardium occidentale L. tree, most commonly known as the Cashew tree. Its annual production in Brazil is around 30 thousand tons just in the northeast, where they have $95 \%$ of the total production [1]. The CG yellowish-brown resin has $\beta$-D-galactose, $\alpha$-D-glucose, arabinose, rhamnose, and glucuronic acid in its composition, which can vary according to the maturity of the tree and to the environmental conditions in which it is found [2].

The physicochemical properties of CG have been obtained since the first available studies dating back to the 1970s [3]. Since then, nanocomposites, biodegradable and stimulus-responsive films, curative materials, topical gel, controlled-release tablets, and food protection have been developed [4]. Although CG has been receiving attention in recent years for a range of applications, most of them are in the initial steps and cover the pharmaceutical [5] and veterinary [6] areas.

Once its potential as an anti-inflammatory, gastroprotective, and wound dressing did not show any dermatological reaction, and the cell viability indicates promising biocompatibility, the CG also had its potential as a drug delivery system tested $[4,7,8]$. The CG was produced by self-assembly to carry indomethacin, grafted by radical polymerization to become $\mathrm{pH}$-responsive and deliver epirubicin, made by nanoprecipitation or dialysis to incorporate and deliver diclofenac diethylamine, and acetylated to encapsulate and release amphotericin B, epiisopiloturine, indomethacin, and insulin [7-12]. What these studies have in common is that they prove the potential of the CG to encapsulate and deliver the hydrophobic drug, as well as to encapsulate oils [13-18].

$\alpha$-Tocopherol is a potent antioxidant oil with the highest biological activity among the lipophilic antioxidants because of its potential to neutralize reactive oxygen species (ROS) and to reduce peroxinitrite and lipid peroxidation while stabilizing the nucleoprotein structure [19]. The potential of $\alpha$-tocopherol to enhance the effect of cell protection is responsible for its wide use in food, cosmetics and pharmaceutical industries. Its sensitivity to light, heat, oxygen, and reduced bioavailability, however, limits its application $[20,21]$. In this work, we aimed to explore the best method for extraction of cashew gum and to develop nanoparticles for the delivery and protection of $\alpha$-tocopherol.

\section{Materials and Methods}

\subsection{Materials}

Cashew gum was donated by Embrapa (Ceará, Brazil). Sodium hydroxide (CAS number 1310-73-2), hydrogen peroxide (CAS number 7722-84-1), and acetone (CAS number 67-64-1) were bought from Dinâmica (São Paulo, Brazil) and ethanol (CAS number 64-17-5) was purchased from Neon (São Paulo, Brazil). All other reagents were obtained from Sigma-Aldrich (St. Louis, MO, USA). Ultra-pure water (home supplied) was used for all the experiments carried out in this study.

\subsection{Cashew Gum Purification}

The purification of cashew gum was carried out using four methodologies, as illustrated in Figure 1. Briefly, cashew gum $(500 \mu \mathrm{m})$ was firstly dissolved in water for $24 \mathrm{~h}$, followed by filtration and $\mathrm{pH}$ adjustment to 7.0 with $\mathrm{NaOH} 1 \mathrm{M}$. For purifications 1 and 2 (P1 and P2) the methodology described by Rodrigues et al. (1993) was implemented [22]. The solvent used in P1 was hydrogen peroxide and in P2 was acetone. In purification methodology 3 (P3), after dispersing in water for $30 \mathrm{~min}$, cashew gum was sonicated in water by tip ultrasound with a power density of $200 \mathrm{w} / \mathrm{L}$, for $2 \mathrm{~min}$. In purification 4 (P4), cashew gum was stirred in water using a magnetic stirring at $30^{\circ} \mathrm{C}$, power of $50 \mathrm{~W}$, and pressure of 154 bar for $5 \mathrm{~min}$. Then, after vacuum filtration, a mixture of water and ethanol 1:4.5 (water: $\mathrm{EtOH}$ ) was added, allowed to rest for $90 \mathrm{~min}$, discarded the precipitate and dried in a forced circulation oven at $60^{\circ} \mathrm{C}$, for $24 \mathrm{~h}$. Finally, in all methodologies, the purified gum was manually ground using porcelain grit and pestle. 


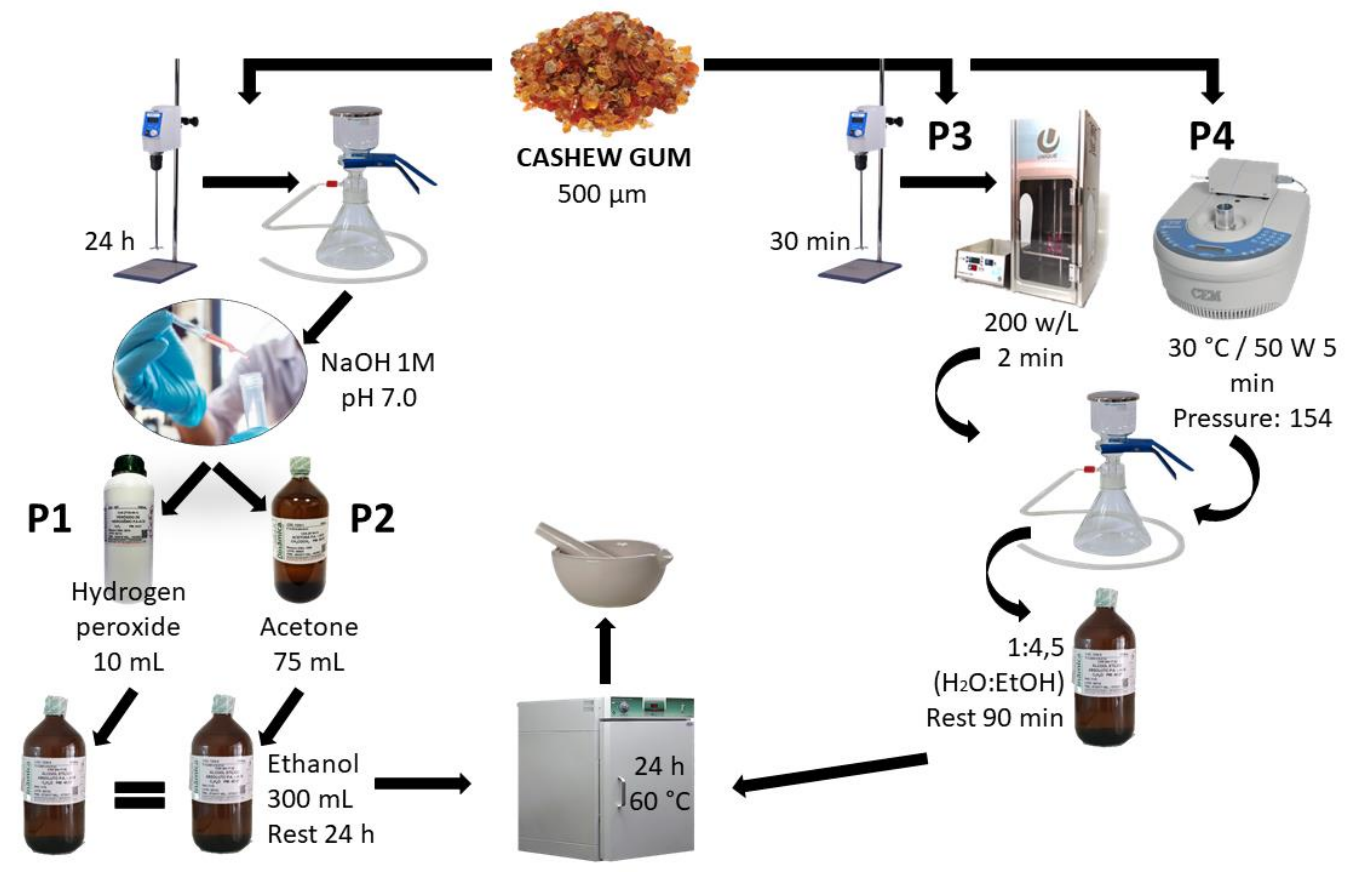

Figure 1. Flowchart of the four methodologies used to purify the cashew gum.

\subsection{Determination of the Production Yield}

The production yield obtained for each of the methodologies used for cashew gum purification was calculated as follows (Equation (1)):

$$
\text { Yield }(\%)=\frac{W_{f}}{W_{i}} \times 100
$$

where $W_{f}$ is the final weight after purification, drying, and maceration, and $W_{i}$ is the initial weight before the purification process.

\subsection{Production of Cashew Gum Particles}

Cashew gum particles were obtained by self-assembly of the resin, applying the method described by Fessi et al. with slight modifications [23]. Briefly, $1 \mathrm{mg} \cdot \mathrm{mL}^{-1}$ of cashew gum was dissolved in an aqueous solution, and different concentrations of $\alpha$ tocopherol $(50 \%, 25 \%$ and $10 \%)$ were dissolved into ethanol. Both solutions were prepared under magnetic stirring (Kasvi, K40-1820 H, São José dos Pinhais, PR, Brazil) for 30 min. After that, the organic phase was poured into the aqueous phase generating the selforganization of the particles. The solvent was removed under reduced pressure (Buchi, R 300, BÜCHI Labortechnik AG, Flawil, Switzerland) at $35^{\circ} \mathrm{C}$, followed by frozen liquid nitrogen and lyophilization process (LaboGene, Bjarkesvej, Denmark). Lastly, the powder samples were stored in an air-tight container for further characterization.

\subsection{Determination of Total Ash and Moisture Content}

The total ash content was measured by the conventional method described previously [24], and calculated using Equation (2):

$$
\text { Total Ash }(\%)=\frac{W_{2}-W_{1}}{W_{3}} \times 100
$$

where $W_{1}$ is the dish weight after calcination and cooling, $W_{2}$ is the dish weight with the sample after calcination and cooling in the desiccator and $W_{3}$ is the initial weight of the sample. The cashew gum residual moisture content was determined after purification using a gravimetric analytical balance with a coupled infrared radiation drying system 
(Shimadzu-MOC-63U, Kyoto, Japan). The samples were placed on aluminum plates and dried in a slow mode at $60^{\circ} \mathrm{C}$. The weight variation was $5 \%$ and with $0.001 \mathrm{~g}$ of accuracy. The data were recorded and expressed as a percentage.

\subsection{Thermal Analysis}

The thermogravimetric analysis (TGA/DTG) of the samples was obtained in a thermobalance model (DTG-60, Shimadzu, Kyoto, Japan), in the range of $10-700{ }^{\circ} \mathrm{C}$ and under a dynamic nitrogen atmosphere $\left(50 \mathrm{~mL} \cdot \mathrm{min}^{-1}\right)$. The cashew gum mass was $8.5 \pm 0.5 \mathrm{mg}$ and the cashew gum NPs mass was $2.5 \pm 0.5 \mathrm{mg}$. The data were recorded in a TA Instruments TRIOS program (Shimadzu, Kyoto, Japan). The differential scanning calorimetry (DSC) analyses were carried out under airflow $\left(45 \mathrm{~mL} \cdot \mathrm{min}^{-1}\right)$ with a Shimadzu DSC-60 plus model (Shimadzu, Kyoto, Japan), at a heating rate of $10^{\circ} \mathrm{C} / \mathrm{min}$ and temperature range between 298.15 to $473.15 \mathrm{~K}\left(25\right.$ to $\left.200{ }^{\circ} \mathrm{C}\right)$ for cashew gum, and 233.15 to $473.15 \mathrm{~K}\left(-40{ }^{\circ} \mathrm{C}\right.$ to $200{ }^{\circ} \mathrm{C}$ ) for cashew gum NPs. The sample mass was $2.0 \pm 0.5 \mathrm{mg}$ [15].

\subsection{Physicochemical Analysis}

The crystallinity was investigated using an X-ray diffractometer (Shimadzu, XRD6000 , Kyoto, Japan) with a $\mathrm{CuK} \alpha$ radiation source. The diffraction patterns were recorded at $40 \mathrm{kV}$ and $30 \mathrm{~mA}$ and the reflection angle $2 \theta$ was monitored from $2-70^{\circ}$. The step size was $0.02(\lambda=1.5406 \mathrm{~nm})$ at a scanning speed of $1^{\circ} \cdot \mathrm{min}^{-1}$ [8]. The infrared spectroscopy was obtained by diffuse reflectance with Fourier transform infra-red (FTIR) (Nicolet IS10, Thermo Scientific, Waltham, MA, USA) using KBr pellets, wave band from 400 to $4000 \mathrm{~cm}^{-1}$, $4 \mathrm{~cm}^{-1}$ of the resolution, and with an accumulation of 32 sweeps [7]. The FTIR spectra were normalized, and the bands of vibration were associated with the main chemical to corroborate the previous physicochemical analyzes of the CG, ${ }^{1} \mathrm{H} N M R$, and ${ }^{13} \mathrm{C}$ NMR spectrometric analysis was also performed. These spectra were obtained by a Varian UV spectrometer (Oxford Instruments, Abington, UK) at $300 \mathrm{MHz}$. The samples were added to $\mathrm{D}_{2} \mathrm{O}$, in a concentration of $100 \mathrm{mg} \cdot \mathrm{mL}^{-1}$. ${ }^{1} \mathrm{H}$ NMR had the $30 \mathrm{~s}$ of relaxation time and a pulse angle of $90^{\circ}$, and ${ }^{13} \mathrm{C}$ NMR had $1 \mathrm{~s}$ of relaxation time and a pulse angle of $30^{\circ}$.

\subsection{Dynamic Light Scattering}

The particle size distribution and the polydispersity index (PDI) were determined by dynamic light scattering (DLS), and the zeta potential (ZP) was determined using electrophoretic mobility measurements using the same instrument. Both measurements were performed using the Zetasizer NanoZS device (Malvern Instruments, Worcestershire, UK) [25]. The stability of the samples was analyzed by monitoring the size by DLS on days $7,14,21$ and 30 . During this period, the samples were stored in glass flasks at $4 \pm 2{ }^{\circ} \mathrm{C}[26]$.

\subsection{Encapsulation Efficiency (EE) and Loading Capacity (LC)}

The encapsulation efficiency (EE) and loading capacity (LC) of $\alpha$-Toc in cashew gum nanoparticles were determined indirectly as described by Somchue et al. with minor modifications [27]. The unloaded oil was quantified by measuring the absorbance at $292 \mathrm{~nm}$ in an Evolution 220 UV-visible spectrophotometer (Thermo Fisher Scientific, Waltham, MA, USA) after centrifugation at $6400 \mathrm{~g}$ (MiniSpin ${ }^{\circledR}$ Plus Microcentrifuges, Prag, Czech Republic). The content was determined against a calibration curve $(Y=0.00303+x, r=0.999986)$ and the percentage of EE and LC was calculated according to Equations (3) and (4):

$$
\begin{aligned}
& \text { EE }(\%)=\frac{(\text { Total mass of drug }- \text { Free drug })}{(\text { Total mass of drug })} \times 100 \\
& L C(\%)=\frac{(\text { Total mass of drug }- \text { Free drug })}{(\text { Particle weight })} \times 100
\end{aligned}
$$




\subsection{Morphological Analysis}

The morphology of the cashew gum NPs was evaluated by transmission electron microscopy (TEM), with the Tecnai G2 Spirit Twin 12 microscope (FEI, Prague, Czech Republic) following previous methodology [28]. The sample was dried quickly using a negative staining protocol and observed in bright field mode under an acceleration voltage of $120 \mathrm{kV}$.

\subsection{In Vitro Release Study}

The in vitro release study was performed according to the method described by Ye et al. [29] in an aqueous solution with Tween $80(0.1 \%)$ at room temperature under gentle agitation $(120 \mathrm{r} / \mathrm{min})$. The nanoparticles (CGNPs+10) were prepared, concentrated approximately $6.5 \times$, and placed in a $2 \mathrm{~mL}$ D-tube ${ }^{\mathrm{TM}}$ dialyzer plastic tube (Sigma-Aldrich, St. Louis, MO, USA). $0.1 \mathrm{~mL}$ of release medium was removed from the dialysis bag at specified time intervals and measured by a UV-visible spectrophotometer at $292 \mathrm{~nm}$ (Thermo Fisher Scientific, Waltham, MA, USA). The study was carried out in triplicate and the $\alpha$-Toc released was shown as the cumulative percentage of $\alpha$-Toc outside the tube over the total of $\alpha$-Toc inside the tube, mean and standard deviation.

\subsection{Cell Viability}

The effect of crude cashew gum, purified cashew gum, $\alpha$-Toc, and cashew gum $\mathrm{NPs}+10$ on the viability of the cells was evaluated using the MTT assay [30] in three distinct cell lines on monkey kidney epithelial cell (LLC-MK 2 ), human liver cell (HepG2), and human monocyte cell (THP1). The sample pellet was dissolved in $200 \mu \mathrm{L}$ of DMSO and the absorbance was measured in an ELISA reader at $570 \mathrm{~nm}$ (SpectraMax Gemini 190, Molecular Devices, San Jose, CA, USA). Each experiment was carried out in triplicate and the final optical density was given by the value of the mean \pm standard deviation of the sample readings, performed in triplicate on the plates, subtracted from the average value of the optical density of the wells containing only the cells. The cytotoxic concentration (CC50) was generated by a $50 \%$ reduction in the optical density value in the 3-(4,5-dimethylthiazol2-yl)-2,5-diphenyltetrazolium bromide (MTT) assay, calculated by regression analysis.

\subsection{Statistic}

All descriptive analysis of CG and their particles, including mean and standard deviation, was used to evaluate the numerical data. To compare the samples, the data were evaluated by the ANOVA test, followed by the Tukey test $(p<0.05)$. Data analysis was performed using the statistical software R [31].

\section{Results and Discussion}

Cashew gum is a brown resin extracted from the tree trunk, which is aggregated with inorganic salts, proteins, lignins, and nucleic acids from adjacent structures [2]. For this reason, and given the need to standardize the material to be worked on, to obtain reproducibility and confidence in the results, it is necessary to purify the cashew gum before its application. Therefore, cashew gum was purified by four different methodologies (P1-P4) to compare them with each other and select the best one for reproduction.

When purified, the samples changed the color (Figure 2A), ranging from a white to light brown powder. This difference may also be related to the maturity of the donor tree and the environment in which it was found [25]. The yield obtained by each methodology was $58.40 \%, 54.36 \%, 72.66 \%$ and $40.61 \%$ for P1-P4, respectively. Previous studies that used the same methodology as P1 and P2 found $67 \%$ and $78 \%$, respectively [32]. The lower yield observed in P1, P2 and P4 may be associated with the amount of solvent and the process used during purification [32]. On the other hand, P3 had the highest yield due to the potential for hydrolysis and polysaccharides cleavage from the ultrasonic probe sonicator used in the process [33]. 
(A)

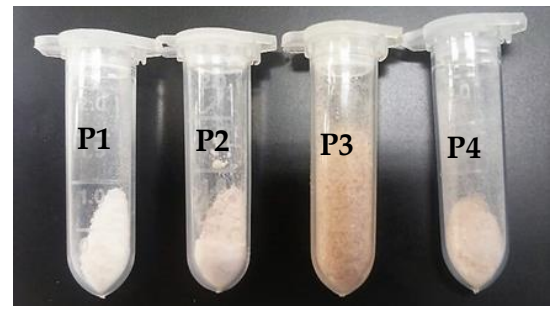

(B)
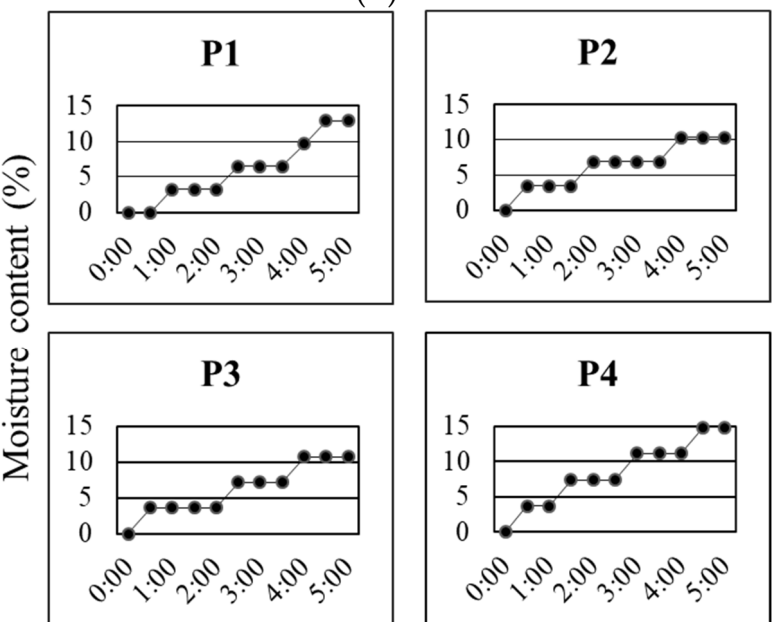

(C)

Time (min)

(D)

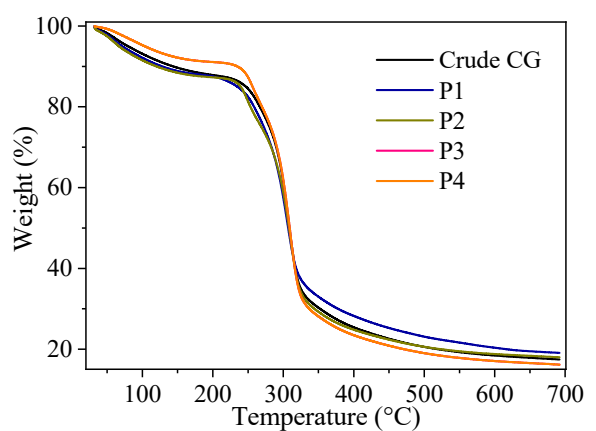

(E)

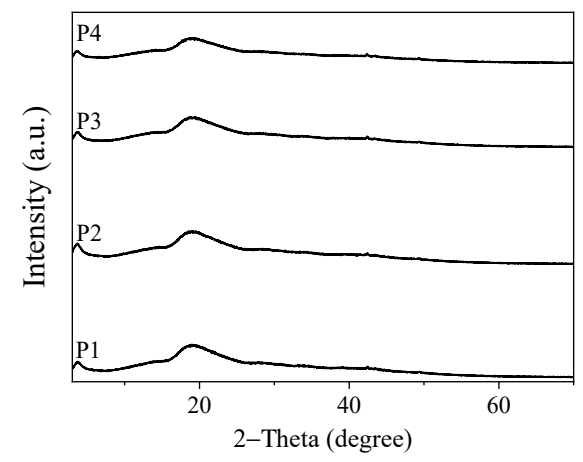

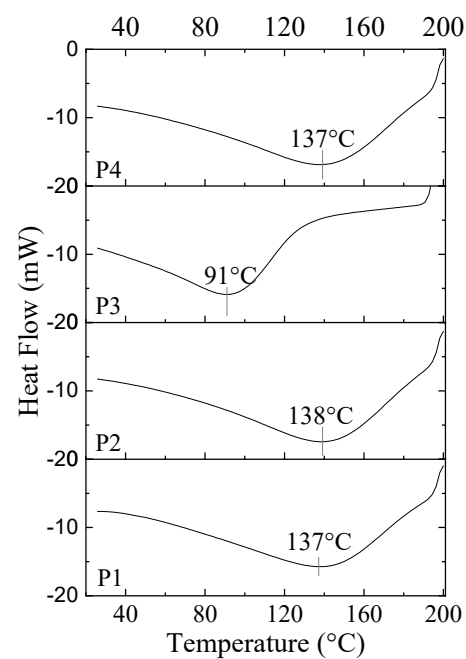

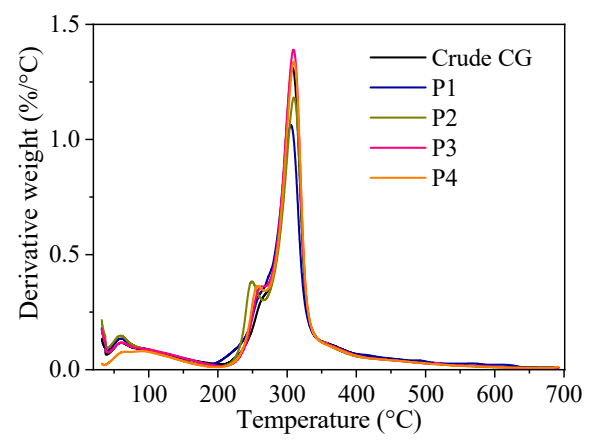

(F)

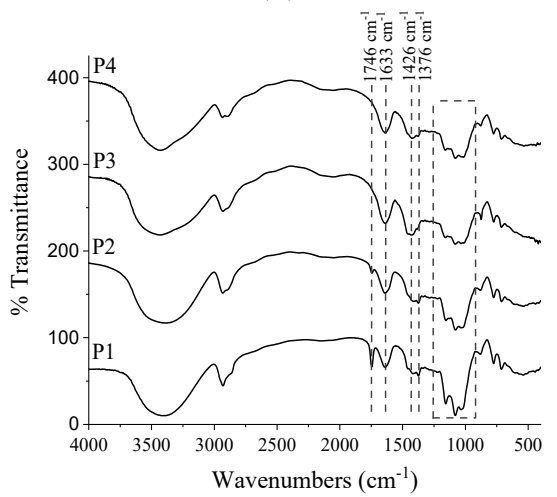

Figure 2. (A) Cashew gum after purification by different methodologies, using hydrogen peroxide (P1), acetone (P2), ultrasonic probe sonicator (P3), and microwave (P4); (B) Percentage of CG moisture content after drying by infrared radiation at $60{ }^{\circ} \mathrm{C}$; (C) DSC curves of CG from room temperature to $473.15 \mathrm{~K}\left(200^{\circ} \mathrm{C}\right)$ and heating rate of $283.15 \mathrm{~K}\left(10^{\circ} \mathrm{C}\right)$; (D) TG/DTG curve of CG under dynamic nitrogen atmosphere $\left(50 \mathrm{~mL} \cdot \mathrm{min}^{-1}\right), \beta=10^{\circ} \mathrm{C}$, and $\mathrm{m}=8.5 \pm 0.5 \mathrm{mg}$; (E) X-ray Diffractogram of CG with $2 \theta$ reflection angle, monitored from $2^{\circ}$ to $70^{\circ}$ at a scan speed of $1^{\circ} \mathrm{min}^{-1}, 40 \mathrm{kV} / 30 \mathrm{~mA}$; (F) FTIR spectra of CG in Kbr pellet. 
The percentage of total ash and the moisture content are critical parameters of fundamental purity to be analyzed, considering that the lower their indexes, the higher the quality of the purified gum [24]. The \% of total ash after the CG purifications were $0.69 \%$, $0.61 \%, 0.34 \%$ and $1.05 \%$ for P1-P4, respectively. Previous studies which used similar methodologies as P1 and P2 had the \% of total ash around 0.95\% [34] and 0.71\% [35], suggesting potential in the addition of hydrogen peroxide and acetone in the process. However, the highlight was the addition of an ultrasonic probe sonicator on P3, which results in less than $0.40 \%$ of ash. The desirable level accepted by the pharmaceutical and food industries is $4 \%$ [24].

The moisture contents were analyzed by the gravimetric method in an analytical balance with coupled infrared radiation drying system. All samples reached the stability of the weight after $5 \mathrm{~min}$, resulting in residual moisture values of $12.9 \%, 10.34 \%, 10.71 \%$ and $14.81 \%$ for P1-P4, respectively (Figure 2B). These percentages are associated with drying efficiency, powder fluidity, viscosity, and storage stability due to their effect on the glass transition and crystallization behavior [36].

The TGA/DTG presented three stages of decomposition for all samples analyzed (Figure 2C). The first event it was in the temperature range $25-197{ }^{\circ} \mathrm{C}$ with a variation of $\Delta \mathrm{m}_{1}=11.55 \%$ and $\mathrm{T}_{\text {peak DTG }}=55.59{ }^{\circ} \mathrm{C} ; \Delta \mathrm{m}_{1}=11.87 \%$ and $\mathrm{T}_{\text {peak DTG }}=54.97^{\circ} \mathrm{C}$; $\Delta \mathrm{m}_{1}=11.96 \%$ and $\mathrm{T}_{\text {peak DTG }}=56.22{ }^{\circ} \mathrm{C}$; and $\Delta \mathrm{m}_{1}=8.74 \%$ and $\mathrm{T}_{\text {peak DTG }}=86.05{ }^{\circ} \mathrm{C}$ for $\mathrm{P} 1-\mathrm{P} 4$, respectively. This first step is widely elucidated in the literature and is related to the loss of free and bound water molecules of the CG [37].

It is well-known that the gums, in general, present a mainly double decomposition pattern, and this stage starts above $200{ }^{\circ} \mathrm{C}$ [38]. The second stage was observed around $240^{\circ} \mathrm{C}$, which is associated with the degradation of low molecular weight proteins and polysaccharide components of the gum [37]. The total mass loss until this stage was $\Delta \mathrm{m}_{1}=26.14 \%$ and $\mathrm{T}_{\text {peak DTG }}=258.24{ }^{\circ} \mathrm{C} ; \Delta \mathrm{m}_{1}=23.42 \%$ and $\mathrm{T}_{\text {peak DTG }}=249.53^{\circ} \mathrm{C} ; \Delta \mathrm{m}_{1}=22.81 \%$ and $\mathrm{T}_{\text {peak DTG }}=260.72{ }^{\circ} \mathrm{C}$; and $\Delta \mathrm{m}_{1}=19.40 \%$ and $\mathrm{T}_{\text {peak DTG }}=268.80^{\circ} \mathrm{C}$ for P1-P4, respectively. The sample of methodology $\mathrm{P} 4$ has a lower percentage of low molecular weight molecules, while the methodology P2 and P3 did not influence this percentage. These temperatures and losses demonstrate a thermal pattern already exposed in the literature [16,37].

The total degraded after the third peak mass loss reached $\Delta \mathrm{m}_{1}=65.24 \%$ and $\mathrm{T}_{\text {peak DTG }}=306.72{ }^{\circ} \mathrm{C} ; \Delta \mathrm{m}_{1}=69.21 \%$ and $\mathrm{T}_{\text {peak DTG }}=311.07{ }^{\circ} \mathrm{C} ; \Delta \mathrm{m}_{1}=72.29 \%$ and $\mathrm{T}_{\text {peak DTG }}=309.83{ }^{\circ} \mathrm{C} ; \Delta \mathrm{m}_{1}=70.27 \%$ and $\mathrm{T}_{\text {peak DTG }}=310.45^{\circ} \mathrm{C}$ for P1-P4, respectively. The residual weight at $700{ }^{\circ} \mathrm{C}$ were $\Delta \mathrm{m}_{1}=19.21 \%, \Delta \mathrm{m}_{1}=18.10 \%, \Delta \mathrm{m}_{1}=14.22 \%$ and $\Delta \mathrm{m}_{1}=16.16 \%$ for P1-P4, respectively, confirming the degradation behavior of the samples, seen in the ash content, where P3 has the lowest residual mass.

Responsible for evaluating water loss, protein denaturation, crystallization, oxidation behavior, and thermophysical properties of materials, the DSC is an important tool for associating moisture content with TGA/DTG. In a nitrogen atmosphere, the DSC curve exhibited an endothermic event between the room temperature and $463.15 \mathrm{~K}\left(190^{\circ} \mathrm{C}\right)$, with peaks in the range of $410.15 \mathrm{~K}\left(137^{\circ} \mathrm{C}\right)$ for $\mathrm{P} 1, \mathrm{P} 2$ and $\mathrm{P} 4$, and a peak shifted to the left for $\mathrm{P} 3$, at $363.47 \mathrm{~K}\left(90.32{ }^{\circ} \mathrm{C}\right)$ (Figure 2D). The endothermic events presented are attributed to moisture evaporation, corroborating with the TGA/DTG.

The diffractograms (Figure 2E) show that the different methodologies of purification did not modify the amorphous characteristics of the CG. This is due to the broad projections presented by the $C G$, without peak formation and with $2 \theta=18.9^{\circ}$. When modifications occur during the process, a disorder in the structure can be generated, leading to material amorphization due to the breakage of chemical bonds and breakage or melting of the chains in the crystalline region of the material. Other studies presented the same amorphous characteristic $[16,39]$.

The FTIR spectra (Figure 2F) show a slight difference between the samples P1 and P2 from the samples P3 and P4; however, they all had CG characteristic bands. The common bands between all spectra are the wavelengths of $1633 \mathrm{~cm}^{-1}$ and $1426 \mathrm{~cm}^{-1}$ (asymmetric and symmetrical stretches of COO-), $1157 \mathrm{~cm}^{-1}, 1082 \mathrm{~cm}^{-1}$ and $1025 \mathrm{~cm}^{-1}$ associated with 
-CO elongation and glycosidic bond (C-O-C) of the polysaccharide [7,37]. Important to highlight that $\mathrm{P} 1$ and $\mathrm{P} 2$ were the only samples that present bands between $1376 \mathrm{~cm}^{-1}$ and $1746 \mathrm{~cm}^{-1}$ of the ester groups, commonly found in acetylated CG [7,9]. With these initial results and following the objective of the proposed study, methodology 3 was chosen to purify the CG to continue the development of the work.

The CG particles were produced by the nanoprecipitation technique, a methodology widely used to encapsulate hydrophobic substances and obtain spherical particles [40]. Particle size analysis by DLS showed, in solution, diameters ranging from 300 to $600 \mathrm{~nm}$ (Table 1). The CG alone was not able to form particles, but when associated with $\alpha$-Toc, resulted in submicron particles, suggesting that CG acted as a surfactant in the formulation (Figure 3).

Table 1. Analysis of the size, polydispersity index, zeta potential, encapsulation efficiency, and loading capacity of cashew gum particles with different concentrations (50\%, 25\% and $10 \%$ ) of $\alpha$-Tocopherol.

\begin{tabular}{cccccccc}
\hline Samples & $\begin{array}{c}\text { Volume } \\
\mathbf{( d \cdot n m )}\end{array}$ & $\begin{array}{c}\text { Size } \\
\mathbf{( d \cdot n m )}\end{array}$ & $\begin{array}{c}\text { Number } \\
\mathbf{( d \cdot n m )}\end{array}$ & PDI & $\begin{array}{c}\text { ZP } \\
(\mathbf{m V})\end{array}$ & E.E. (\%) & L.C. (\%) \\
\hline CG & $7.0 \pm 2.64$ & - & - & - & $-2.98 \pm 0.91$ & - & - \\
CGNPs+50 & $645.9 \pm 69.7$ & $562.96 \pm 32.26 \mathrm{a}$ & $506.73 \pm 40.59 \mathrm{a}$ & $0.14 \pm 0.07 \mathrm{a}$ & $-25.8 \pm 0.81 \mathrm{a}$ & $99.93 \pm 0.104 \mathrm{a}$ & $32.92 \pm 0.365$ \\
CGNPs+25 & $624.4 \pm 44.88$ & $535.00 \pm 28.12 \mathrm{a}$ & $459.37 \pm 29.37 \mathrm{a}$ & $0.18 \pm 0.04 \mathrm{a}$ & $-23.9 \pm 0.78 \mathrm{a}$ & $100.00 \pm 0.742 \mathrm{a}$ & $19.76 \pm 0.080$ \\
CGNPs+10 & $448.4 \pm 39.19$ & $370.97 \pm 55.80 \mathrm{~b}$ & $315.70 \pm 79.83 \mathrm{~b}$ & $0.16 \pm 0.02 \mathrm{a}$ & $-24.6 \pm 1.31 \mathrm{a}$ & $100.00 \pm 0.379 \mathrm{a}$ & $8.91 \pm 0.089$ \\
\hline
\end{tabular}

$\mathrm{a}$, b: significant difference comparing groups with different concentrations $(p<0.05)$. CG = cashew gum; GCNPs $+50=$ cashew gum particle with $50 \%$ of $\alpha$-Tocopherol; GCNPs $+25=$ cashew gum particle with $25 \%$ of $\alpha$-Tocopherol; GCNPs $+10=$ cashew gum particle with $10 \%$ of $\alpha$-Tocopherol; PDI = polydispersity; ZP = Zeta Potential; E.E. = Encapsulation Efficiency; L.C. = Loading Capacity.

Size

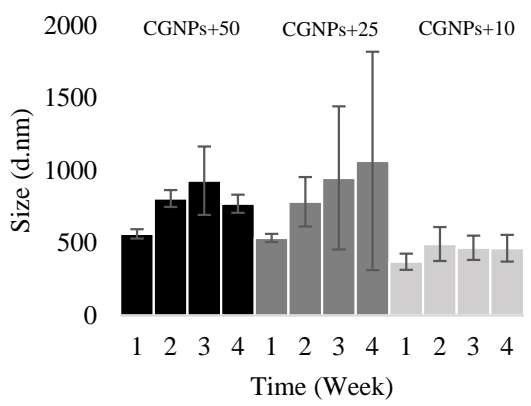

(A)

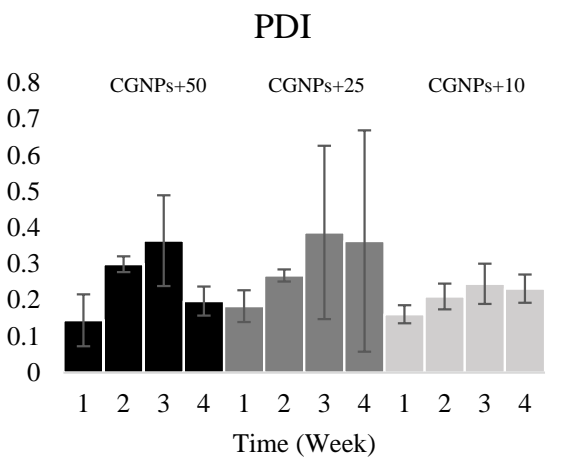

(C)

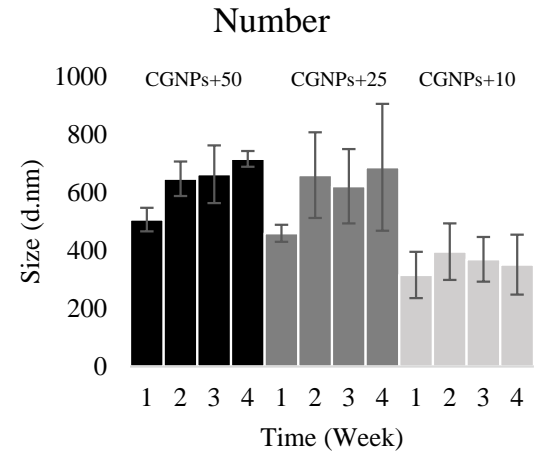

(B)

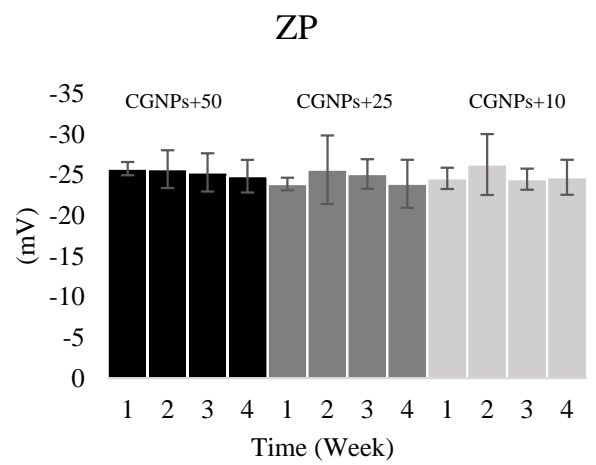

(D)

Figure 3. Physicochemical stability of CG particles with different concentrations of $\alpha$-tocopherol in 30 days: (A) Size, (B) Number, (C) PDI and (D) ZP. Data represent mean \pm standard deviation of $\mathrm{n}=3$; Where: CGNPs $+50=$ cashew gum nanoparticle with $50 \%$ of $\alpha$-Tocopherol; CGNPs $+25=$ cashew gum nanoparticle with $25 \%$ of $\alpha$-Tocopherol; CGNPs +10 = cashew gum nanoparticle with $10 \%$ of $\alpha$-Tocopherol; PDI = polydispersity; ZP = Zeta Potential. 
The biggest particles had $50 \%(w / w)$ of $\alpha$-Toc and an average size of $645.9 \pm 69.70 \mathrm{~nm}$, whereas the smallest sized particles were recorded at $315.70 \pm 79.83 \mathrm{~nm}$ for the lowest $\alpha$-Toc concentration, $10 \%(w / w)$. With $25 \%(w / w)$ of $\alpha$-Toc, the particle size was around $535.00 \pm 28.12 \mathrm{~nm}$, but when analyzed by number, it is possible to identify a dominant population around $459.37 \pm 29.37 \mathrm{~nm}$. The mean particle size is indeed very much governed by the oil content and production procedure and does not compromise the oral administration route. More important than the mean particle size is the polydispersity (PDI), as it translates the long-term stability of the dispersions if lower than $<0.2$, a value that characterizes the dispersions as monodispersed [41]. Nanoprecipitation technique is a widely known technique commonly used in the production of both nanospheres (to load hydrophobic/hydrophilic drugs) and nanocapsules (to load mineral oils), including $\alpha$-Tocopherol [23]. This was the technique we used to prepared our particles, in which the cashew gum was solubilized in the aqueous phase and the $\alpha$-Tocopherol in the organic phase. As Martínez Rivas et al. suggest [40], the organic phase was injected in the aqueous phase, generating supersaturation, nucleation, growth and coagulation. According to Noronha et al. [42], the cashew gum worked as a surfactant, where the hydrocarbon chains of $\alpha$-Tocopherol interact with the hydrophobic region of the cashew gum, which makes it surrounding the oil, protecting it. This is possible to observe with the negative zeta potential of the particles, the same charge of cashew gum, and with better stability once the value decreases to approximately $-24 \mathrm{mV}$.

The particle' surface charge was recorded as the measure of the zeta potential (ZP), an important parameter for the characterization of the drug delivery system, once it can determine the interaction of the particles with the cells and the physical stability of the dispersion [39]. The ZP of CG purified (Table 1) showed a negative charge, $-2.98 \mathrm{mV}$, and the $\alpha$-Toc has reported in the literature a positive charge $(+13.1 \mathrm{mV})$. The obtained $\mathrm{ZP}$ for the particles can suggest an electrostatic interaction between them since opposite surface charges are one of the main binding forces between the compounds when mixed to form particles or complexes [43]. After obtaining the particles with both components, the complex presented $\mathrm{ZP}$ in the range of -23.9 to -25.8 , emphasizing the negative charge presented by CG and suggesting the gum in the outer layer. These results mean a homogeneous dispersion with moderate stability of the particles [15].

Although the particles are stable, they are influenced by the concentration of $\alpha$-Toc in their size. Using $6400 \times g$ in centrifugation, we have seen that cashew gum nanoparticles were separated enough to allow sampling an aliquot of supernatant for the measurements of unloaded oil. The $\alpha$-Toc encapsulation efficiency was above $99 \%$ in all formulations (Table 1), in contrast with a previous study with CG for oil encapsulation, in which the maximum encapsulation efficiency was 93\% [17]. Inversely proportional to E.E., the L.C. tends to increase when the active incorporated concentration gets higher. This behavior can be observed in Table 1, where CGNPs +50 presented $32.92 \pm 0.365 \%$ of $\alpha$-Toc in the final formulation, and the others CGNPs+25 $19.76 \pm 0.080 \%$ and CGNPs $+108.91 \pm 0.089 \%$.

The solution stability is influenced by numerous factors, including the adsorption of surface-active molecules and the use of surfactant in the synthesis of particle aggregation, the chemical composition of the components, and also the premature release of the active principle [8]. Therefore, the stability of the case was analyzed by DLS immediately after synthesis and during the following 4 weeks (Figure 3).

The particles showed excellent stability when analyzed macroscopically, and did not present visual sedimentation, flocculation, or even a creamy appearance during the study period. The visual analysis corroborates with DLS results, which show that there was no significant variation among the evaluated points, between the weeks, observing the samples individually. On the other hand, the variation in size by the number of their populations maintained from the 2 nd week of storage the CGNPs+25 and CGNPs+50 with no significant difference between them, unlike CGNPs+10. 
The CGNPs+25 showed a higher standard deviation for size and PDI over the weeks of storage; however, it was not a significant variation. The CGNPs+10 showed the smallest variation in size, number, and PDI among all particles, over the entire period evaluated.

These results confirm the ZP initially presented by the particles. The ZP of the particles did not show significant variation over time, presenting negative zeta, which results in lower cellular absorption and also low cell cytotoxicity, and in the range of $-20 \mathrm{mV}$, which is considered an acceptable stability range. The same stability can be seen in a study with $\alpha$-Toc encapsulated in niosomes that presented $\mathrm{ZP}$ in the same $\mathrm{mV}$ range [44].

The thermal analysis aims to evaluate chemical reactions, physical properties, and structural changes that may occur due to the temperature imposed on the material. These temperatures, evaluated by TGA/DTG, are displayed in curves in Figure 4A. The first stage presented by CGNPs was observed up to $125^{\circ} \mathrm{C}$ and is related to the moisture content evaporation. This stage resulted in a mass variation of $\Delta \mathrm{m}_{1}=2.69 \%$ and $\mathrm{T}_{\text {peak } \mathrm{DTG}}=53.18^{\circ} \mathrm{C}$; $\Delta \mathrm{m}_{1}=2.43 \%$ and $\mathrm{T}_{\text {peak DTG }}=52.92{ }^{\circ} \mathrm{C}$; and $\Delta \mathrm{m}_{1}=2.34 \%$ and $\mathrm{T}_{\text {peak }}$ DTG $=56.98{ }^{\circ} \mathrm{C}$ for CGNPs+10, CGNPs+25 and CGNPs+50, respectively. It is noteworthy that the complex CG and $\alpha$-Toc had fewer hydrogen bonds in its composition, resulting in lower moisture and consequently loss of mass in this first stage, compared to CG alone (Figure 2C).

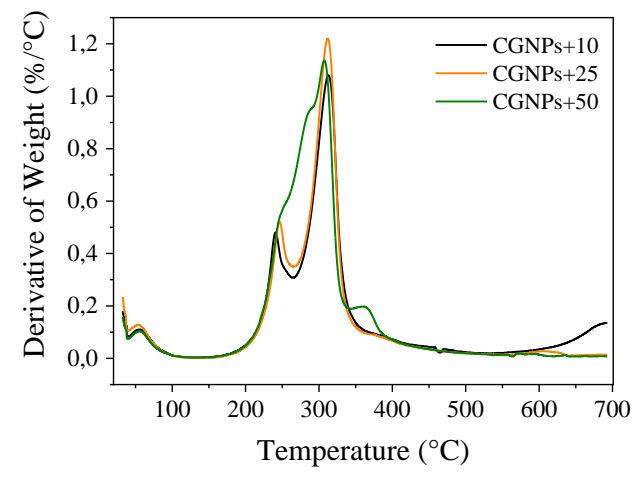

(A)

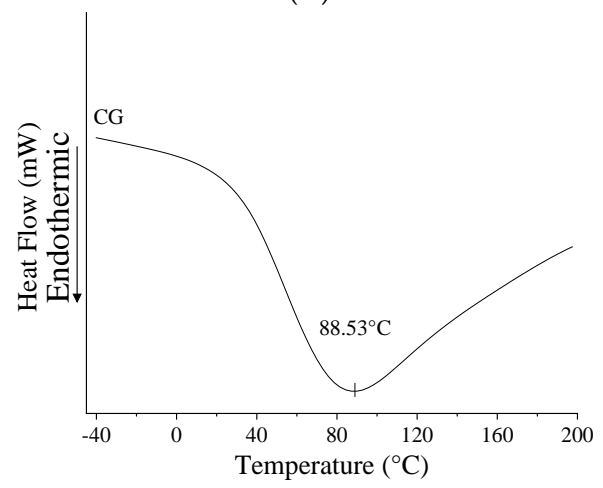

(C)

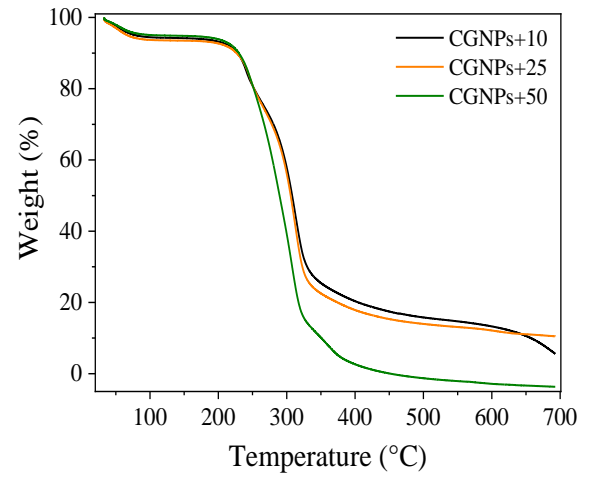

(B)

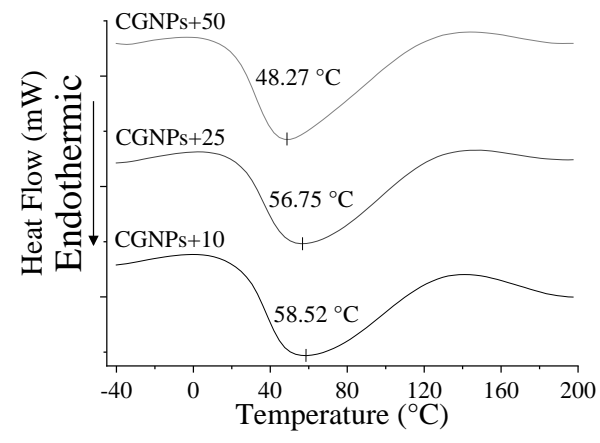

(D)

Figure 4. (A) Derivative thermogravimetric (TGA/DTG) curve and (B) termogravimetric analysis (TGA) of the CG particles with dif-ferent concentrations of $\alpha$-tocopherol obtained under dynamic nitrogen atmosphere $\left(50 \mathrm{~mL} \cdot \mathrm{min}^{-1}\right), \beta=10^{\circ} \mathrm{C} \cdot \mathrm{s}^{-1}$, and $\mathrm{m}=2.5 \pm 0.5 \mathrm{mg}$; (B) DSC curves of CG and (C) DSC curve of crude CG, and (D) DSC curves of CGNPs with different concentrations of $\alpha$-tocopherol; Where: CGNPs $+50=$ cashew gum nanoparticle with $50 \%$ of $\alpha$-Tocopherol; CGNPs +25 = cashew gum nanoparticle with $25 \%$ of $\alpha$-Tocopherol; CGNPs $+10=$ cashew gum nanoparticle with $10 \%$ of $\alpha$-Tocopherol.

The second and third stages are directly linked and are attributed to the depolymerization and formation of residues of the particles. Both are well defined and show the same behavior for CGNPs+10 and CGNPs+25 with $\Delta \mathrm{m}_{1}=17.17 \%$ and $\mathrm{T}_{\text {peak DTG }}=239.26{ }^{\circ} \mathrm{C}$; and $\Delta \mathrm{m}_{1}=17.75 \%$ and $\mathrm{T}_{\text {peak DTG }}=244.45^{\circ} \mathrm{C}$ in the second stage, and $\Delta \mathrm{m}_{1}=48.98 \%$ and 
$\mathrm{T}_{\text {peak DTG }}=313.85^{\circ} \mathrm{C}$; and $\Delta \mathrm{m}_{1}=50.37 \%$ and $\mathrm{T}_{\text {peak DTG }}=312.88^{\circ} \mathrm{C}$ in the third stage. On the other hand, the CGNPs+50 showed the second and third stages melted and slightly smaller, with $\Delta \mathrm{m}_{1}=76.49 \%$ and $\mathrm{T}_{\text {peak DTG }}=307.06^{\circ} \mathrm{C}$. The same happened when the $\alpha$-Toc was added in greater quantity in the mixture of $\mathrm{PVOH}$ and starch. Furthermore, CGNPs+50 was the only one to present the fourth event with $\Delta \mathrm{m}_{1}=8.97 \%$ and $\mathrm{T}_{\text {peak DTG }}=360.89^{\circ} \mathrm{C}$. This event is associated with the aromatic structure of the oil decomposing [21].

The residual weight of the particles was smaller than CG alone, and it is possible to observe that the lower the concentration of $\alpha$-Toc, the greater the final residue (Table 2). The residual mass for CGNPs+10, CGNPs+25 and CGNPs+50, respectively, were $12.47 \%$, $11.56 \%$ and $0 \%$. In this complex, CG is the most stable component, despite studies claiming that the association with $\alpha$-Toc has the potential to increase thermal stability and reduce mass loss at high temperatures [45]. In this case, the $\alpha$-Toc concentration had no relevant influence on the thermal stability of the particles, the same behavior was also observed in chitosan films [21].

Table 2. Parameters of the CGNPs third stage degradation with different concentrations of $\alpha$ tocopherol. $\mathrm{D}_{0.1}$ : initial decomposition temperature; $\mathrm{D}_{1 / 2}$ : temperature values for the $50 \mathrm{wt} . \%$; MRTD: the temperature for the maximum rate of decomposition; Residue: residue obtained at $600{ }^{\circ} \mathrm{C}$.

\begin{tabular}{ccccc}
\hline Sample/Parameters & $\mathbf{D}_{\mathbf{0 . 1}}$ & $\mathbf{D}_{\mathbf{1 / 2}}$ & MRTD & The Residue (\%) \\
\hline CGNPs+10 & 272.23 & 312.44 & 330.82 & 12.47 \\
CGNPs+25 & 277.28 & 312.13 & 330.79 & 11.56 \\
CGNPs+50 & 265.29 & 308.23 & 327.87 & 0.0 \\
\hline
\end{tabular}

According to DSC analysis (Figure 4B), CGNPs+10 showed a melting endothermic peak at $331.67 \mathrm{~K}\left(58.52{ }^{\circ} \mathrm{C}\right)$, being slightly more stable than the other particles, which had a melting endothermic peak at $329.90 \mathrm{~K}\left(56.75^{\circ} \mathrm{C}\right)$ and $321.42 \mathrm{~K}\left(48.27^{\circ} \mathrm{C}\right)$ for CGNPs+25 and CGNPs+50, respectively. This endothermic peak along with the thermogravimetric event is widely reported in the literature as water loss and suggests weak links between both components, once the CGNPs were less stable than CG alone.

Even within a wide temperature range, 233.15 to $473.15 \mathrm{~K}$ ( -40 to $200^{\circ} \mathrm{C}$ ), both CG and CGNPs did not show glass transition, which was not possible to identify their transition from amorphous to viscous state. The amorphous state of CG has been reported, and its X-ray diffractogram shows a broad peak at $2 \theta=23^{\circ}$ [15]. Due to $\alpha$-Toc encapsulation, CGNPs had the peak shifted to $13.9^{\circ}, 17.8^{\circ}$ and $18.0^{\circ}$ for CGNPs+10, CGNPs+25, and CGNPs+50, respectively (Figure 5A).

The FTIR spectra (Figure 5B) of CG, $\alpha$-Toc, and CGNPs+10 explain the possible interaction between the two components. The $\alpha$-Toc spectrum shows important bands that characterize the oil, such as the bands $2845 \mathrm{~cm}^{-1}$ and $2782 \mathrm{~cm}^{-1}\left(\mathrm{CH}_{2}\right.$ stretch vibration), $1269 \mathrm{~cm}^{-1}$ (C-O ethers), and $1058 \mathrm{~cm}^{-1}$ (phenyl elongation) [46]. When observing the CGNPs, it is not possible to identify differences between them and CG, as they present the same unmodified bands, which suggests total encapsulation of $\alpha$-Toc, corroborating the E.E. and the ZP. These data stand out from a previous study that tried to encapsulate a mix of oils and it was possible to identify the main bands of each component of the nanocapsule produced; however, they only had $13.4 \%$ of E.E. [47]. On the other hand, another study that obtained E.E. above $95 \%$ showed the FTIR spectrum of the complex with a slight difference in the intensity, suggesting the influence of oil concentration and E.E. in the results [48]. The CGNPs+10 analyzed by transmission electron microscopy (Figure 6) was produced by nanoprecipitation and presented a spherical shape with good delimitation, and without roughness. They have size uniformity (Figure $6 \mathrm{~B}$ ) by the PDI, and an average size around $150 \mathrm{~nm}$ (Figure 6A), being a little smaller than those observed by DLS. In addition, white spots can be seen inside the particles, which suggests the $\alpha$-Toc inside them. 


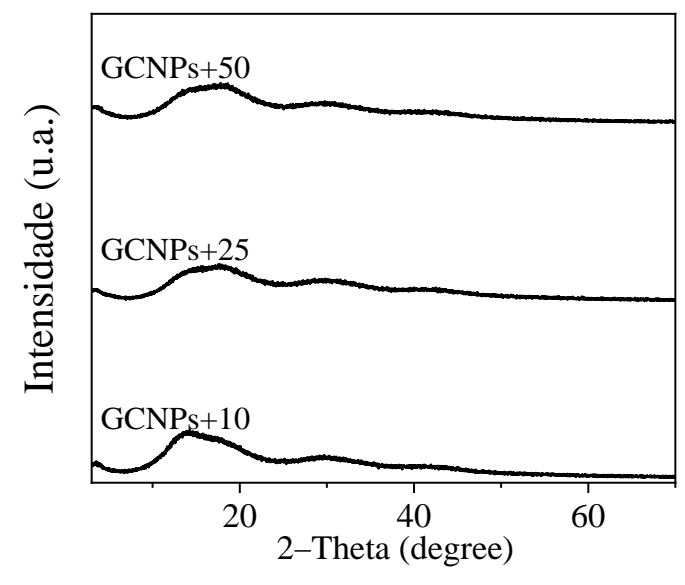

(A)

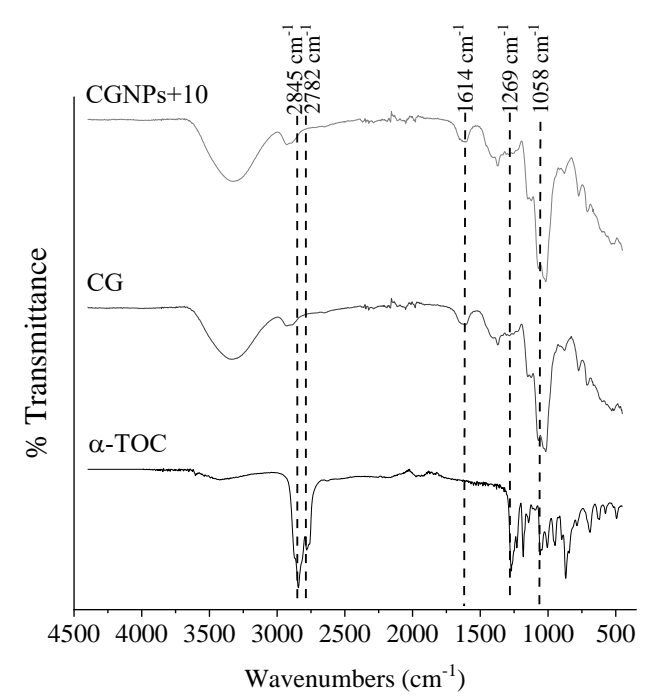

(B)

Figure 5. (A) X-ray diffractogram of the cashew gum particles (CGNPs) with different concentrations of $\alpha$-tocopherol $(10 \%, 25 \%$ and $50 \%)$, and with $2 \theta$ reflection angle, monitored from $2^{\circ}$ to $70^{\circ}$ at a scan speed of $1^{\circ} \cdot \mathrm{min}^{-1}, 40 \mathrm{kV} / 30 \mathrm{~mA}$; (B) FTIR spectrum of cashew gum (CG), $\alpha$-tocopherol ( $\alpha$-TOC), and CGNPs with $10 \%$ of $\alpha$-tocopherol.

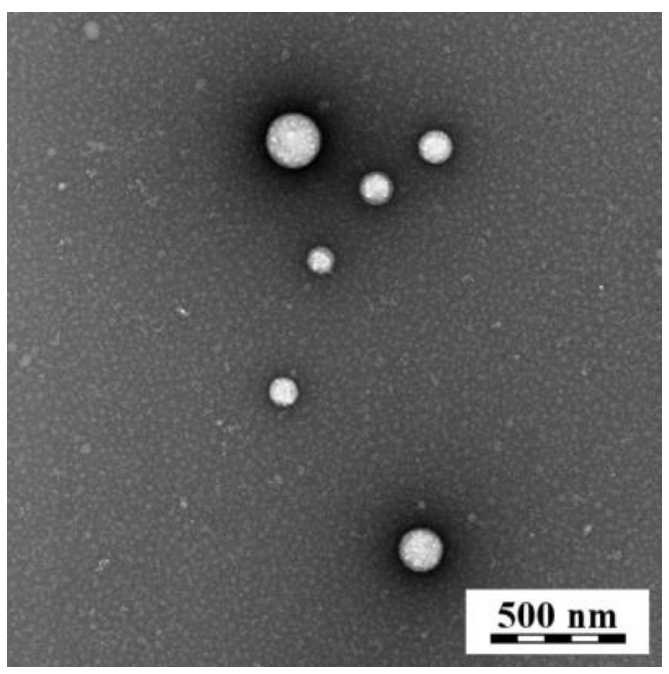

(A)

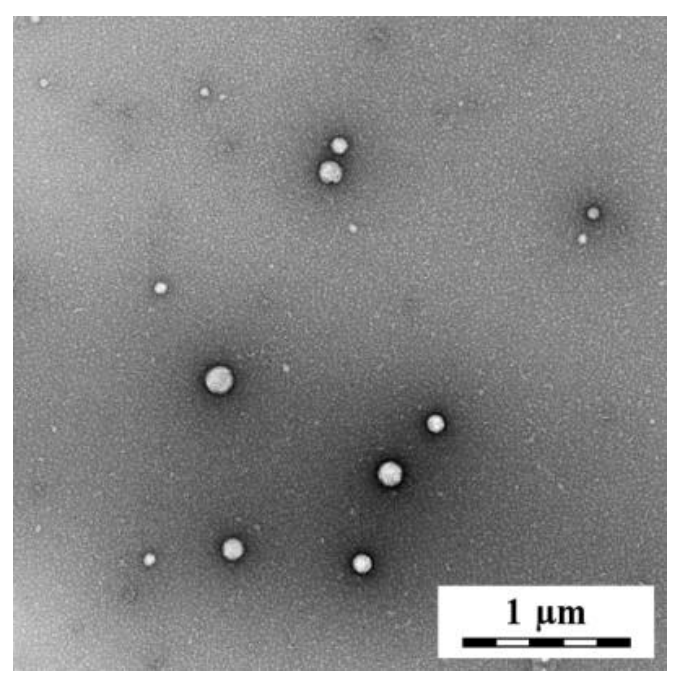

(B)

Figure 6. Transmission electron microscopy of the cashew gum particles with $10 \%$ of $\alpha$-tocopherol $($ CGNPs+10) prepared by nanoprecipitation, on the scale $500 \mathrm{~nm}(\mathbf{A})$ and $1 \mu \mathrm{m}(\mathbf{B})$.

To understand the behavior mechanism of CGNPs, the duration of $\alpha$-Toc delivery, and based on the results obtained previously, CGNPS+10 was chosen for in vitro release analysis. Figure 7 shows the amount $\alpha$-Toc from CGNPs +10 released as a function of time, where it can be seen that in general $\alpha$-Toc has a slow, continuous, and gradual release profile, reaching equilibrium after $12 \mathrm{~h}$ of release with $15.2 \% \alpha$-Toc released from CGNPs+10 when reaching that plateau. The CG behavior can be observed in other studies, where even carrying a drug with the same load, the CG requires more time to release a larger volume [11,39]. 


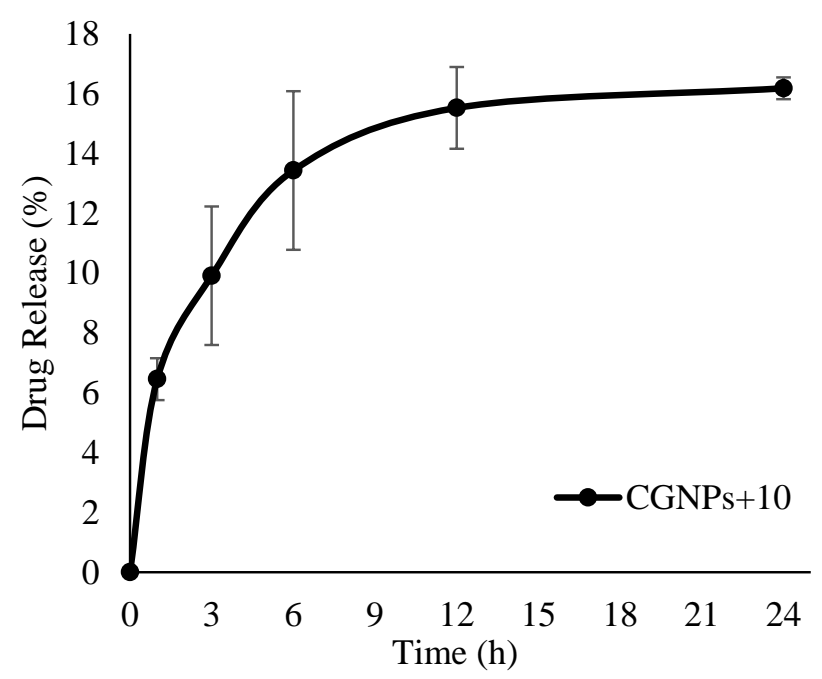

Figure 7. Cumulative percentage of $\alpha$-tocopherol release from CGNPs +10 . Mean \pm SD, $n=3$. $\mathrm{Y}=0.00303+\mathrm{x}, \mathrm{r}=0.99986$.

To determine the drug release mechanism, the R2 mathematical models were statistically analyzed by the SigmaPlot 14.0 software and presented in Table 3. For each sample, the Korsmeyer-Peppas [49], Hixon and Crowel [50], Higuchi [51] and First Order [52] models were analyzed, according to the release data obtained. The Korsmeyer-Peppas model showed the highest value when compared to the other models, $R^{2}=1$, and it is possible to state that this study follows this mechanism model. The Korsmeyer-Peppas model is calculated by $\mathrm{Mt} / \mathrm{M} \infty=\mathrm{kt}^{\mathrm{n}}$, where the exponent ' $\mathrm{n}$ ' determines the release mechanism according to the geometry of the system. If your system is a sphere, with the ' $\mathrm{n}$ ' value equal to $\mathrm{n}=0.43, \mathrm{n}=0.43<\mathrm{m}<0.85$, and $\mathrm{n}=0.85$, it can be classified into Fickian, Anomalous Transport, or Case-II Transport, respectively [53].

Table 3. Coefficient of in vitro release of different mathematical models for $\alpha$-tocopherol and the cashew gum particle with $10 \%$ of $\alpha$-tocopherol (CGNPs+10).

\begin{tabular}{cc}
\hline Mathematical Models & r Squared Value $\mathbf{( r}^{\mathbf{2}}$ ) CGNPs+10 \\
\hline Korsmeyer-Peppas & 1 \\
Hixon and Crowell & 0.999611 \\
Higuchi & 0.927562 \\
First Order & 0.999137 \\
\hline
\end{tabular}

Case-II transport is an anomalous diffusion, where the particle behavior entails in the medium dissolution and the polymer passes through a glass-rubber transition, which means that drug release is dominated by polymer disentanglement and erosion [49,54].

The cytotoxic concentration (CC50) determined the effect of different concentrations of CG, purified CG, $\alpha$-Toc, and CGNPs+10 on LLC-MK2, HepG2 and THP- 1 after $48 \mathrm{~h}$ by the MTT assay. Given the data, absorbance was added in a linear relationship to determine the concentrations of interest (Figure 8A-C). The results of crude CG purified CG and $\alpha$-Toc were clear when they did not show any toxicity for the three cell lines tested. However, some concentrations above $125 \mu \mathrm{g}$ were not statistically significant when compared to the control. The only sample which influenced the three cell lines was CGNPs+10. Assuming that CGNPs+10 is a spherical particle, with an average size of $370 \mathrm{~nm}$ and negative ZP, it is possible to suggest an influence of these characteristics with the CC50 results. The CGNPs+10 showed CC50 of $296.2 \mu \mathrm{g} / \mathrm{mL}, 397.3 \mu \mathrm{g} / \mathrm{mL}$ and $606.6 \mu \mathrm{g} / \mathrm{mL}$ for THP-1, HepG2 and LLC-MK2, respectively. These results demonstrate that CGNPs+10 preserve the characteristics of $\alpha$-tocopherol and direct its activity, acting uniquely in each cell line. Among the cell lines tested, CGNPs +10 had the highest efficacy in HepG2 with $76.85 \%$ of 
cell mortality with $500 \mu \mathrm{g} / \mathrm{mL}$, and the lowest efficacy was against LLC-MK ${ }_{2}$, with only $32.24 \%$ of toxicity at the same concentration. The THP- 1 was the cell line that required the lowest concentration to eliminate $50 \%$ of it, which may be linked to its high and professional power of particle phagocytosis. The CGNPs+10 behavior and its isolated components were already observed in a previous study, where a complex with $\alpha$-tocopherol showed cytotoxic activity against $4 \mathrm{~T} 1$ cells (murine mammary carcinoma), while its free and isolated forms did not show any activity [55].

(A)
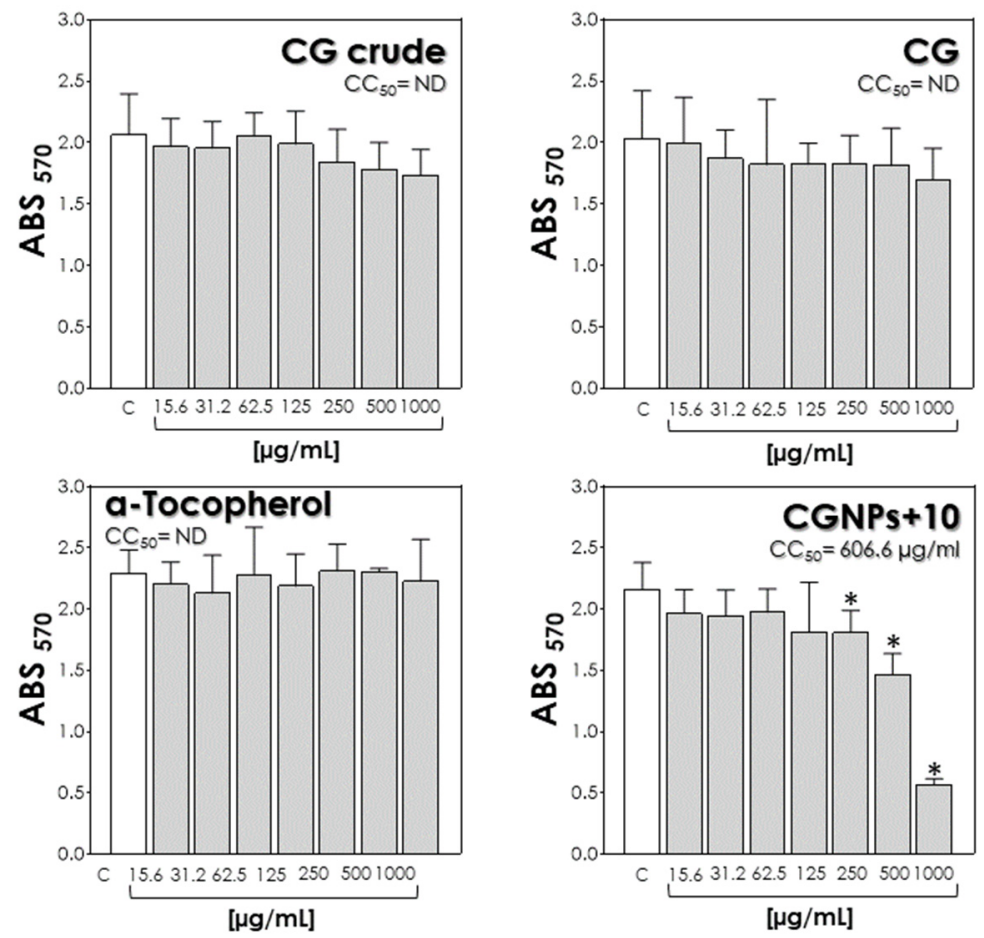

(B)

(C)
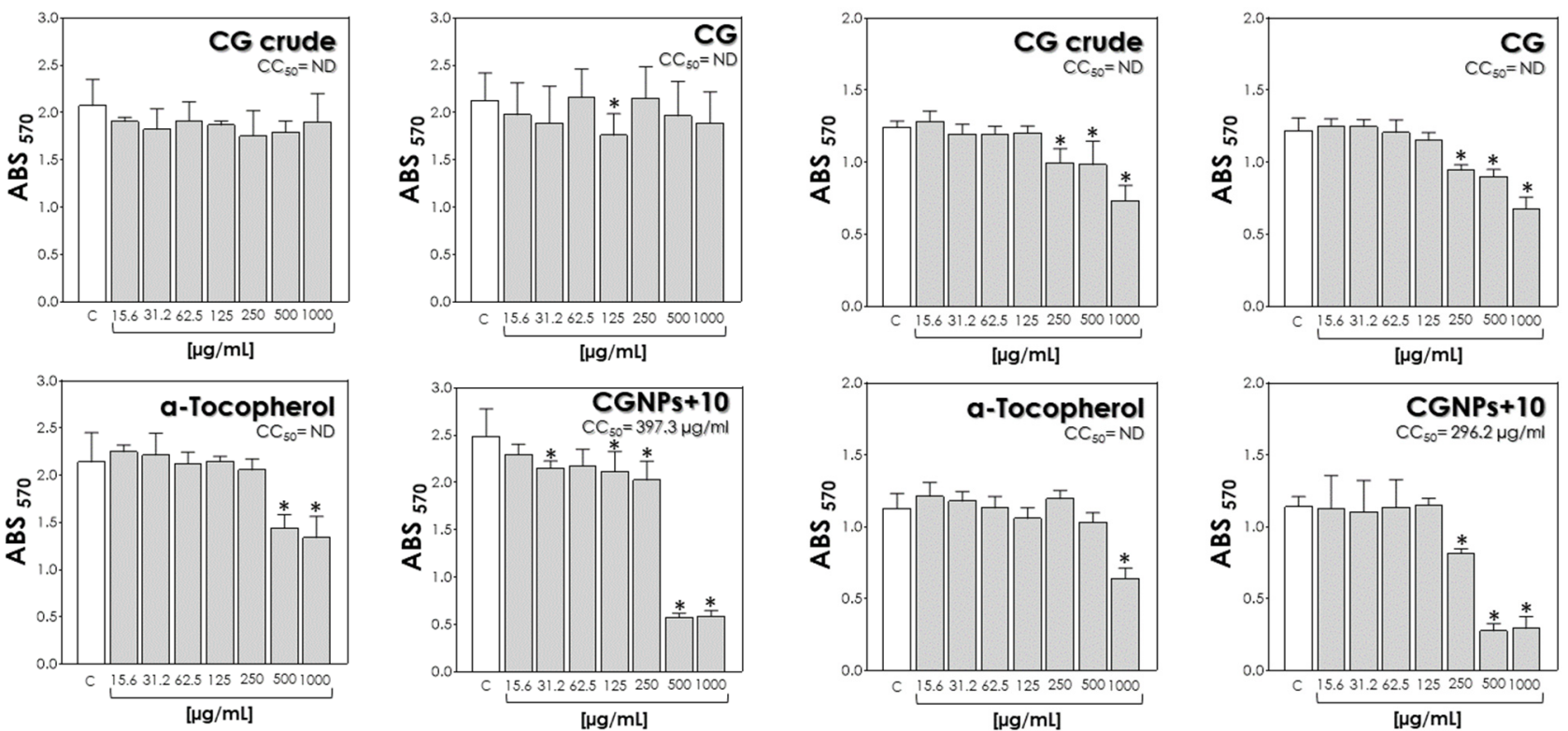

Figure 8. Cell viability of CG crude, CG after purification, $\alpha$-tocopherol, and CGNPs+10 on (A) LLC-MK2, (B) HepG2, and (C) THP-1(MФ). MTT assay was conducted on these cells which were treated with different concentrations of each component for $48 \mathrm{~h}$. The data represents the mean \pm standard deviation of $n=3$; * significant difference comparing the control $(p<0.05)$. CG: cashew gum, CGNPs+10: cashew gum particle with $10 \%$ of $\alpha$-tocopherol. 


\section{Conclusions}

CGNPs were prepared by nanoprecipitation with different concentrations of $\alpha$-Toc, and the physicochemical characterization might suggest its encapsulation. The $\alpha$-Toc concentration influences directly the encapsulation efficiency and the particle size. With a spherical shape, the best particle presented $370.97 \pm 55.80 \mathrm{~nm}, 100 \%$ of encapsulation efficiency, $8.91 \pm 0.089 \%$ of loading content, and polydispersity $0.16 \pm 0.02$. On the other hand, the Zeta potential did not have a significant difference between the formulations. In terms of stability, all formulations presented good macroscopic stability, but when verified by DLS, the CGNPs+10 shows the smallest size variation and polydispersity during 30 days. By TEM was possible to see the spherical submicron particles loaded with $\alpha$-Toc, in agreement with the previous results and suggesting a nanocapsule. Moreover, the $\alpha$-Toc release profile and the mathematical models revealed that when the $\alpha$-Toc are loaded in a CG capsule, the CGNPs protect the $\alpha$-Toc of the media and can deliver a bigger amount of the hydrophobic oil on the target site. The effectiveness of CGNPs+10 on cells with high proliferation capacity and abnormal characteristics is clear, offering them different applications with their cytotoxic action against abnormal cells and antioxidant action against normal cells. Lastly, the results reinforce the capacity to developing a new nanosystem with $\alpha$-Toc, more biocompatible and that can be used in different delivery systems for different purposes.

Author Contributions: K.C.L., A.J., E.P., I.B.L.-V., P.Š., L.S.S., A.L.S.S. and M.V.C. contributed to the conceptualization, methodology, validation, formal analysis, and investigation, and writing —original draft preparation. H.S.B., M.F.L.R.S., R.L.C.d.A.-J., J.C.C., E.B.S., M.d.C.M. and P.S. contributed to the supervision, writing - review and editing, project administration, resources, and funding acquisition. All authors have made a substantial contribution to the work. All authors have read and agreed to the published version of the manuscript.

Funding: This research received funding from the Coordenação Aperfeiçoamento de Pessoal de Nivel Superior (CAPES), Fundação de Ámparo à Pesquisa do Estado de Sergipe (FAPITEC) (PROCESSO: 88887.159533/2017-00 extração, encapsulação e caracterização de bioativos para o interesse biotecnologico) and Conselho Nacional de Desenvolvimento Científico e Tecnológico (CNPq 301964/2019-0 Chamada 06/2019, and Chamada CNPq n ${ }^{\circ}$ 01/2019), from Portuguese Foundation for Science and Technology (FCT/MEC) through national funds, and co-financed by FEDER, under the Partnership Agreement PT2020 for the project UIDB/04469/2020.

Institutional Review Board Statement: Not applicable.

Informed Consent Statement: Not applicable.

Data Availability Statement: Not applicable.

Conflicts of Interest: The authors declare no conflict of interest.

\section{References}

1. Silva, R.A.O.; Marques, L.G.A.; de Freitas, R.M.; dos Santos, M.d.S.F.; avalcanti da Silva Filho, E.; do Ó Pessoa, C.; Santos, M.R.d.M.C. Prospecção tecnológica: Aplicação da goma do cajueiro (Anacardium occidentale) em nanotecnologia. Rev. Geintec-Gest. Inov. E Tecnol. 2013, 3, 55-69. [CrossRef]

2. Ribeiro, A.J.; de Souza, F.R.L.; Bezerra, J.M.; Oliveira, C.; Nadvorny, D.; Monica, F.; Nunes, L.C.; Silva-Filho, E.C.; Veiga, F.; Sobrinho, J.L.S. Gums' based delivery systems: Review on cashew gum and its derivatives. Carbohydr. Polym. 2016, 147, 188-200. [CrossRef]

3. Anderson, D.M.; Bell, P.C.; Millar, J.R. Composition of gum exudates from Anacardium occidentale. Phytochemistry 1974, 13, 2189-2193. [CrossRef]

4. Kamminga, T.; Slagman, S.J.; Martins Dos Santos, V.A.P.; Bijlsma, J.J.E.; Schaap, P.J. Risk-Based Bioengineering Strategies for Reliable Bacterial Vaccine Production. Trends Biotechnol. 2019, 37, 805-816. [CrossRef]

5. Bezerra, J.M.; Oliveira, A.C.; Silva-Filho, E.C.; Severino, P.; Souto, S.B.; Souto, E.B.; Soares, M.F.L.R.; Soares-Sobrinho, J.L. The Potential Role of Polyelectrolyte Complex Nanoparticles Based on Cashew Gum, Tripolyphosphate and Chitosan for the Loading of Insulin. Diabetology 2021, 2, 107-116. [CrossRef]

6. Loureiro, K.C.; Lima-Verde, I.B.; Johannisson, A.; Ntallaris, T.; Jager, A.; Štěpánek, P.; da Costa Mendonça, M.; Severino, P.; Morrell, J.M. Effects of cashew gum and nanoparticles on cooled stallion semen. Acta Vet. Scand. 2020, 62, 31. [CrossRef] 
7. Dias, S.F.L.; Nogueira, S.S.; de França Dourado, F.; Guimarães, M.A.; de Oliveira Pitombeira, N.A.; Gobbo, G.G.; Primo, F.L.; de Paula, R.C.M.; Feitosa, J.P.A.; Tedesco, A.C. Acetylated cashew gum-based nanoparticles for transdermal delivery of diclofenac diethyl amine. Carbohydr. Polym. 2016, 143, 254-261. [CrossRef]

8. do Amaral Rodrigues, J.; de Araújo, A.R.; Pitombeira, N.A.; Plácido, A.; de Almeida, M.P.; Veras, L.M.C.; Delerue-Matos, C.; Lima, F.C.D.A.; Neto, A.B.; de Paula, R.C.M. Acetylated cashew gum-based nanoparticles for the incorporation of alkaloid epiisopiloturine. Int. J. Biol. Macromol. 2019, 128, 965-972. [CrossRef] [PubMed]

9. Pitombeira, N.A.; Neto, J.G.V.; Silva, D.A.; Feitosa, J.P.; Paula, H.C.; de Paula, R.C. Self-assembled nanoparticles of acetylated cashew gum: Characterization and evaluation as potential drug carrier. Carbohydr. Polym. 2015, 117, 610-615. [CrossRef] [PubMed]

10. Abreu, C.M.; Paula, H.C.; Seabra, V.; Feitosa, J.P.; Sarmento, B.; de Paula, R.C. Synthesis and characterization of non-toxic and thermo-sensitive poly ( $\mathrm{N}$-isopropylacrylamide)-grafted cashew gum nanoparticles as a potential epirubicin delivery matrix. Carbohydr. Polym. 2016, 154, 77-85. [CrossRef] [PubMed]

11. Lima, M.R.; Paula, H.C.; Abreu, F.O.; da Silva, R.B.; Sombra, F.M.; de Paula, R.C. Hydrophobization of cashew gum by acetylation mechanism and amphotericin B encapsulation. Int. J. Biol. Macromol. 2018, 108, 523-530. [CrossRef] [PubMed]

12. Cardial, M.R.L.; Paula, H.C.; da Silva, R.B.C.; da Silva Barros, J.F.; Richter, A.R.; Sombra, F.M.; de Paula, R.C. Pickering emulsions stabilized with cashew gum nanoparticles as indomethacin carrier. Int. J. Biol. Macromol. 2019, 132, 534-540. [CrossRef] [PubMed]

13. Paula, H.C.; Sombra, F.M.; de Freitas Cavalcante, R.; Abreu, F.O.; de Paula, R.C. Preparation and characterization of chitosan/cashew gum beads loaded with Lippia sidoides essential oil. Mater. Sci. Eng.: C 2011, 31, 173-178. [CrossRef]

14. Abreu, F.O.; Oliveira, E.F.; Paula, H.C.; de Paula, R.C. Chitosan/cashew gum nanogels for essential oil encapsulation. Carbohydr. Polym. 2012, 89, 1277-1282. [CrossRef]

15. de Oliveira, E.F.; Paula, H.C.; de Paula, R.C. Alginate/cashew gum nanoparticles for essential oil encapsulation. Colloids Surf. B Biointerfaces 2014, 113, 146-151. [CrossRef]

16. de Barros Fernandes, R.V.; Botrel, D.A.; Silva, E.K.; Borges, S.V.; de Oliveira, C.R.; Yoshida, M.I.; de Andrade Feitosa, J.P.; de Paula, R.C.M. Cashew gum and inulin: New alternative for ginger essential oil microencapsulation. Carbohydr. Polym. 2016, 153, 133-142. [CrossRef]

17. Botrel, D.A.; Borges, S.V.; de Barros Fernandes, R.V.; Antoniassi, R.; de Faria-Machado, A.F.; de Andrade Feitosa, J.P.; de Paula, R.C.M. Application of cashew tree gum on the production and stability of spray-dried fish oil. Food Chem. 2017, 221, 1522-1529. [CrossRef] [PubMed]

18. de Oliveira, W.Q.; Wurlitzer, N.J.; de Oliveira Araújo, A.W.; Comunian, T.A.; Bastos, M.d.S.R.; de Oliveira, A.L.; Magalhães, H.C.R.; Ribeiro, H.L.; de Figueiredo, R.W.; de Sousa, P.H.M. Complex coacervates of cashew gum and gelatin as carriers of green coffee oil: The effect of microcapsule application on the rheological and sensorial quality of a fruit juice. Food Res. Int. 2020, 131, 109047. [CrossRef]

19. Pezo, F.; Yeste, M.; Zambrano, F.; Uribe, P.; Risopatrón, J.; Sánchez, R. Antioxidants and their effect on the oxidative/nitrosative stress of frozen-thawed boar sperm. Cryobiology 2021, 98, 5-11. [CrossRef]

20. Nogueira, B.; Sampaio, B.; Souza, M.; Costa e Silva, E.; Zuccari, C. Coenzyme Q10 and $\alpha$-Tocopherol Prevent the Lipid Peroxidation of Cooled Equine Semen. Reprod. Domest. Anim. 2015, 50, 1003-1010. [CrossRef] [PubMed]

21. Martins, J.T.; Cerqueira, M.A.; Vicente, A.A. Influence of $\alpha$-tocopherol on physicochemical properties of chitosan-based films. Food Hydrocoll. 2012, 27, 220-227. [CrossRef]

22. Rodrigues, J.F.; de Paula, C.R.M.; Costa, S.M.O. Métodos de isolamento de gomas naturais: Comparação através da goma do cajueiro (Anacardium occidentale L.). Polímeros Ciência E Tecnol. 1993, 3, 31-36.

23. Fessi, H.; Puisieux, F.; Devissaguet, J.P.; Ammoury, N.; Benita, S. Nanocapsule formation by interfacial polymer deposition following solvent displacement. Int. J. Pharm. 1989, 55, R1-R4. [CrossRef]

24. Hakeem, R.B.; Opoku-Ameyaw, K.; Ellis, W.O.; Oldham, J.; Amoah, F.; Oduro, I.; Gyedu-Akoto, E. Physico-chemical properties of cashew tree gum. Afr. J. Food Sci. 2008, 2, 60-64.

25. de Oliveira, A.M.; Jäger, E.; Jäger, A.; Stepánek, P.; Giacomelli, F.C. Physicochemical aspects behind the size of biodegradable polymeric nanoparticles: A step forward. Colloids Surf. A Physicochem. Eng. Asp. 2013, 436, 1092-1102. [CrossRef]

26. Pooja, D.; Panyaram, S.; Kulhari, H.; Rachamalla, S.S.; Sistla, R. Xanthan gum stabilized gold nanoparticles: Characterization, biocompatibility, stability and cytotoxicity. Carbohydr. Polym. 2014, 110, 1-9. [CrossRef]

27. Somchue, W.; Sermsri, W.; Shiowatana, J.; Siripinyanond, A. Encapsulation of $\alpha$-tocopherol in protein-based delivery particles. Food Res. Int. 2009, 42, 909-914. [CrossRef]

28. Schlachet, I.; Trousil, J.; Rak, D.; Knudsen, K.D.; Pavlova, E.; Nyström, B.; Sosnik, A. Chitosan-graft-poly (methyl methacrylate) amphiphilic nanoparticles: Self-association and physicochemical characterization. Carbohydr. Polym. 2019, 212, 412-420. [CrossRef] [PubMed]

29. Ye, F.; Astete, C.E.; Sabliov, C.M. Entrapment and delivery of $\alpha$-tocopherol by a self-assembled, alginate-conjugated prodrug nanostructure. Food Hydrocoll. 2017, 72, 62-72. [CrossRef]

30. Mosmann, T. Rapid colorimetric assay for cellular growth and survival: Application to proliferation and cytotoxicity assays. J. Immunol. Methods 1983, 65, 55-63. [CrossRef]

31. Team, R. A Language and Environment for Statistical Computing [Internet]; R Foundation for Statistical Computing: Vienna, Austria, 2012.

32. Rodrigues, R.; Grosso, C. Cashew gum microencapsulation protects the aroma of coffee extracts. J. Microencapsul. 2008, 25, 13-20. [CrossRef] 
33. Klein, J.M.; Silva de Lima, V.; Couto da Feira, J.M.; Nichele Brandalise, R.; de Camargo Forte, M.M. Chemical modification of cashew gum with acrylamide using an ultrasound-assisted method. J. Appl. Polym. Sci. 2016, 133, 43634. [CrossRef]

34. Da Silveira Nogueira Lima, R.; Rabelo Lima, J.; Ribeiro de Salis, C.; de Azevedo Moreira, R. Cashew-tree (Anacardium occidentale L.) exudate gum: A novel bioligand tool. Biotechnol. Appl. Biochem. 2002, 35, 45-53. [CrossRef] [PubMed]

35. Naka, T.; Martin, D.K.; Soumaila, D.; Simplice, G.T.; Patrice, K.L.; Abrogoua, N. Some physico-chemical properties of cashew gum from cashew exudates and its use as clarifying agent of juice from cashew apple. Agric. Biol. J. N. Am. 2016, 7, 107-115.

36. Mahdavi, S.A.; Jafari, S.M.; Assadpoor, E.; Dehnad, D. Microencapsulation optimization of natural anthocyanins with maltodextrin, gum Arabic and gelatin. Int. J. Biol. Macromol. 2016, 85, 379-385. [CrossRef]

37. Oliveira, M.; Furtado, R.; Bastos, M.; Leitão, R.; Benevides, S.; Muniz, C.; Cheng, H.; Biswas, A. Performance evaluation of cashew gum and gelatin blend for food packaging. Food Packag. Shelf Life 2018, 17, 57-64. [CrossRef]

38. Silva, D.A.; Feitosa, J.P.; Maciel, J.S.; Paula, H.C.; de Paula, R.C. Characterization of crosslinked cashew gum derivatives. Carbohydr. Polym. 2006, 66, 16-26. [CrossRef]

39. Vasconcelos Silva, E.L.; Oliveira, A.C.J.; Patriota, Y.B.G.; Ribeiro, A.J.; Veiga, F.; Hallwass, F.; Silva-Filho, E.C.; da Silva, D.A.; Soares, M.F.R.; Wanderley, A.G.; et al. Solvent-free synthesis of acetylated cashew gum for oral delivery system of insulin. Carbohydr. Polym. 2019, 207, 601-608. [CrossRef]

40. Martínez Rivas, C.J.; Tarhini, M.; Badri, W.; Miladi, K.; Greige-Gerges, H.; Nazari, Q.A.; Galindo Rodríguez, S.A.; Román, R.; Fessi, H.; Elaissari, A. Nanoprecipitation process: From encapsulation to drug delivery. Int. J. Pharm. 2017, 532, 66-81. [CrossRef]

41. Camli, S.T.; Buyukserin, F.; Balci, O.; Budak, G.G. Size controlled synthesis of sub-100 nm monodisperse poly(methylmethacrylate) nanoparticles using surfactant-free emulsion polymerization. J. Colloid Interface Sci. 2010, 344, 528-532. [CrossRef]

42. Noronha, C.M.; Granada, A.F.; de Carvalho, S.M.; Lino, R.C.; de, O.B.; Maciel, M.V.; Barreto, P.L.M. Optimization of $\alpha$-tocopherol loaded nanocapsules by the nanoprecipitation method. Ind. Crop. Prod. 2013, 50, 896-903. [CrossRef]

43. Luo, Y.; Zhang, B.; Whent, M.; Yu, L.L.; Wang, Q. Preparation and characterization of zein/chitosan complex for encapsulation of $\alpha$-tocopherol, and its in vitro controlled release study. Colloids Surf. B Biointerfaces 2011, 85, 145-152. [CrossRef] [PubMed]

44. Basiri, L.; Rajabzadeh, G.; Bostan, A. $\alpha$-Tocopherol-loaded niosome prepared by heating method and its release behavior. Food Chem. 2017, 221, 620-628. [CrossRef] [PubMed]

45. Sin, L.T.; Bee, S.T.; Tee, T.T.; Kadhum, A.A.; Ma, C.; Rahmat, A.R.; Veerasamy, P. Characterization of $\alpha$-tocopherol as interacting agent in polyvinyl alcohol-starch blends. Carbohydzr. Polym. 2013, 98, 1281-1287. [CrossRef]

46. He, J.; Shi, H.; Huang, S.; Han, L.; Zhang, W.; Zhong, Q. Core-Shell Nanoencapsulation of $\alpha$-Tocopherol by Blending Sodium Oleate and Rebaudioside A: Preparation, Characterization, and Antioxidant Activity. Molecules 2018, 23, 3183. [CrossRef]

47. Hu, J.; Zhang, Y.; Xiao, Z.; Wang, X. Preparation and properties of cinnamon-thyme-ginger composite essential oil nanocapsules. Ind. Crop. Prod. 2018, 122, 85-92. [CrossRef]

48. Ghayempour, S.; Montazer, M.; Mahmoudi Rad, M. Tragacanth gum as a natural polymeric wall for producing antimicrobial nanocapsules loaded with plant extract. Int. J. Biol. Macromol. 2015, 81, 514-520. [CrossRef]

49. Korsmeyer, R.W.; Peppas, N.A. Effect of the morphology of hydrophilic polymeric matrices on the diffusion and release of water soluble drugs. J. Membr. Sci. 1981, 9, 211-227. [CrossRef]

50. Hixson, A.W.; Crowell, J.H. Dependence of Reaction Velocity upon surface and Agitation. Ind. Eng. Chem. 1931, 23, 923-931. [CrossRef]

51. Higuchi, T. Mechanism of sustained-action medication. Theoretical analysis of rate of release of solid drugs dispersed in solid matrices. J. Pharm. Sci. 1963, 52, 1145-1149. [CrossRef]

52. Bravo, S.A.; Lamas, M.C.; Salamón, C.J. In-vitro studies of diclofenac sodium controlled-release from biopolymeric hydrophilic matrices. J. Pharm. Pharm. Sci. 2002, 5, 213-219.

53. Peppas, N.A.; Sahlin, J.J. A simple equation for the description of solute release. III. Coupling of diffusion and relaxation. Int. J. Pharm. 1989, 57, 169-172. [CrossRef]

54. Hao, J.; Fang, X.; Zhou, Y.; Wang, J.; Guo, F.; Li, F.; Peng, X. Development and optimization of solid lipid nanoparticle formulation for ophthalmic delivery of chloramphenicol using a Box-Behnken design. Int. J. Nanomed. 2011, 6, 683-692. [CrossRef]

55. Lages, E.B.; Fernandes, R.S.; Silva, J.O.; de Souza, Â.M.; Cassali, G.D.; de Barros, A.L.B.; Miranda Ferreira, L.A. Co-delivery of doxorubicin, docosahexaenoic acid, and $\alpha$-tocopherol succinate by nanostructured lipid carriers has a synergistic effect to enhance antitumor activity and reduce toxicity. Biomed. Pharm. 2020, 132, 110876. [CrossRef] [PubMed] 